Commission, of the United States fellowship which has been in abeyance since 1928 ; they also include a second Spanish Ramsay fellowship. In addition, the British Ramsay fellowship, held by Dr. E. Gelles, has been renewed for a further year, and an extension of four months has been granted to $H$. Mendel (Netherlands) at the University of Oxford.

\section{The Nature Conservancy: Awards for 1951}

THe Nature Conservancy has announced the following awards of research studentships for postgraduate training in ecology, tenable for periods of up to three years at the universities named. Botany : Miss B. Blanchard (Liverpool) ; D. H. Dalby, Miss J. M. Laptain (University College, London) ; M. C. F. Proctor (Queens' College, Cambridge); R. G. West (Clare College, Cambridge) ; D. A. Robertson (King's College, Newcastle upon Tyne). Palceontology: R. E. H. Reid (University College, London). Zoology : R. D. Hughes (Imperial College of Science and Technology, London); J. D. Lockie (Balliol College, Oxford); A. W. G. Manning (Merton College, Oxford); D. J. Morris (Magdalen College, Oxford); H. Roberts (University College, Southampton); I. W. B. Thornton (Leeds).

\section{Christmas Lectures for Juveniles (London)}

A NUMBER of lectures for juvenile audiences, to be held in London during the Christmas holidays, are being arranged by various organizations. At the Royal Institution (21 Albemarle Street, W.1), the Christmas Lectures "to a juvenile auditory" will be given by Prof. James Gray on "How Animals Move" at 3 p.m. on December 27 and 29, 1951, and January $1,3,5$ and 8, 1952; the fee for these lectures is: juveniles $£ 1$, adults $£ 2$. The Institution of Civil Engineers (Great George Street, S.W.1) is holding three lectures, for boys 13-17 years of age, on "Exploring for Oil", "Transporting Oil in Peace and War (Pluto)", and "Working of an Oil Refinery", to be given at 3 p.na. on Deceniber 28 and 31, 1951, and January 2, 1952, respectively. The Royal Geographical Society (1 Kensington Gore, S.W.7) is arranging a lecture, "Jumbos and Jungles", and a sound film, "Scott's Last Expedition", to be given at 2.30 p.m. on December 28 and 31 , respectively, for which application should be made before Decem. ber 14. At the Institution of Electrical Engineers (Savoy Place, W.C.2) the sixth Christmas lecture of the Institution will be given twice, at $3 \mathrm{p} . \mathrm{m}$. on January 3 and 4, 1952, the subject being "Electricity in Civil Aviation". The Royal Photographic Society (16 Princes Gate, S.W.7) is holding three lectures at 3 p.m. on December 31, 1951, and January 1 and 2, 1952, on "How a Lens Forms an Image", "ThreeDimensional Films", and "The Miracle of the Photographic Emulsion", respectively. In addition, the London County Council is holding twelve lectures on various subjects which will be given in different parts of London between December 31, 1951, and January 4, 1952; applications should be made through the pupil's school.

\section{Scientific Advisers for Civil Defence}

THE Home Secretary has announced that the following men of science have been appointed, in a voluntary capacity, to advise on civil defence in the regions indicated: South Western Region (Bristol) : senior scientific adviser, Prof. W. E. Garner ; scientific advisers, Prof. S. H. Piper and Prof. F. H. New- man. Midland Region (Birmingham) : senior scientific adviser, Prof. H. W. Melville; scientific advisers, Prof. P. B. Moon and Prof. J. R. Squire. London Region: senior scientific adviser, Sir Charles Ellis; scientific advisers, Prof. W. V. Mayneord and Dr. H. N. Rydon. North Midland Region (Nottingham): senior scientific adviser, Prof. L. F. Bates; scientific advisers, Prof. L. Hunter and Dr. D. O. Jordan. Northern Region (Newcastle upon Tyne) : senior scientific adviser, Prof. W. E. Curtis; scientific adviser, Prof. G. R. Clemo. North Eastern Region (Leeds) : senior scientific adviser, Prof. F. W. Spiers ; scientific advisers, Prof. W. Bradley and Prof. W. Sucksmith.

\section{Announcements}

Sir DAvid BRUnt, professor of meteorology in the Imperial College of Science and Technology, University of London, has been appointed to the Board of Directors of the Fulmer Research Institute, Stoke Poges, Bucks. The Institute was founded in 1946 on the initiative of Colonel W. C. Devereux, chairman, and opened officially by Sir Stafford Cripps, then President of the Board of Trade, to carry out sponsored research, the results arising therefrom (including patents) belonging solely to the sponsors.

Dr. D. J. E. Ingram, of New College, Oxford, has been appointed research fellow in the Department of Electronics, University College, Southampton, with effect from January 1, 1952. He will be mainly concerned with the work on microwave spectroscopy which is being carried out at the College.

THE conference this year of the Universities of Great Britain and Northern Ireland, convened by the Committee of Vice-Chancellors and Principals, will be held in the William Beveridge Hall, University Senate House, London, W.C.2, during December 14-15. There will be three sessions, as follows : "The Prccedure for the Selection of Students for Admission to the Universities", "Universities and the Fine Arts" and "Student Health". The conference is only open to delegations appointed by the universities and to specially invited guests. Further details can be obtained from the secretary, Dr. J. F. Foster, at 5 Gordon Square, London, W.C.1.

AN account is given on p. 975 in this issue of the Building Research Congress, 1951, which took place in London during September 11-20. The papers presented at the Congress have been printed in three paper-covered books, one dealing with each Division of the Congress. Copies of these books are now available, price 22s. 6d. each, or $50 s$. for the set of three, from the Organizing Secretary, Building Research Congress, 1951, Building Research Station, Garston, Watford, Herts. The price is reduced in the case of members of bodies which participated in the Congress.

ErratuM. In the communication by Prof. T. Urbański entitled "New Derivatives of Nitroparaffins and Antitubercular and Antirickettsial Properties" in Nature of September 29, p. 562, formula (III) was incorrectly written; it should be:<smiles>CCCCC(CCCC)(CN(CO)CO)CC(CC)(CC)[N+](=O)[O-]</smiles> 